\title{
A compilation of 800 word neighborhoods by frequency
}

\author{
LEE M. STADTLANDER \\ Montana State University, Bozeman, Montana
}

\begin{abstract}
A number of inconsistencies are evident in the literature examining word-neighborhood size and frequency effects. One reason for the inconsistency may be that there are no standardized materials and criteria used in the different studies. Each experimenter has devised his or her word neighborhoods using different criteria for neighborhood size and frequency. The purpose of the present study was to develop a standardized set of word neighborhoods. Eight hundred orthographic neighborhoods were constructed with 4- and 5-letter words. The word lists were devised relative to the key elements that have been identified in the literature: (1) target-word frequency, (2) number of words in the neighborhood, (3) number of words higher in frequency than the target word, (4) number of letter positions contributing to the neighborhood, and (5) summation of the frequency of all neighbors (providing a standard metric for high- vs. low-frequency neighborhoods).
\end{abstract}

The average adult reader of English has at least 50,000 words in his or her vocabulary (Monsell, Doyle, \& Haggard, 1989). These 50,000 words are constructed from the set of 26 letters in the alphabet. Furthermore, all of the 26 letters are constructed from a small set of features (Andrews, 1992; Gibson, 1969). Logically, many words must share features and letters with other words. Yet, amazingly, the reader selects the correct word (i.e., lexical entry) from the many possible candidates in memory.

Selection of the correct lexical entry from all other possible candidates is one of the most fundamental issues in models of word recognition. The selection process provides an insight into how lexical memory (i.e., the lexicon) is structured and organized. All models or theories of the recognition process speculate on the way that the lexicon is organized (typically, by visual or phonological features) and, in turn, suggest a method of finding a specific item that has been "filed" in the lexicon. Such theoretical frameworks provide hypothetical points in the selection process that may be tested experimentally. For example, if the mental lexicon is organized by the visual or phonological features of the lexical entries, then an experimenter should be able to influence a subject's response to a stimulus word that has features similar to those of many lexical entries in memory.

This logic was applied in an experiment by Coltheart, Davelaar, Jonasson, and Besner (1977, Experiment 2). Coltheart et al. controlled the similarity of the features of a series of word and nonword stimuli that varied by what they

The author would like to offer her appreciation to R. Peereman and to an anonymous reviewer for insightful comments. This study was funded by a grant from the Montana Women's NSF/EPSCoR Program. To receive a copy of the detailed computerized listing of all word neighborhoods, send a DOS-formatted disk to L. M. Stadtlander, Department of Psychology, Montana State University, Bozeman, MT 59717 (e-mail: upyls@gemini.oscs.montana.edu). called "N," or "orthographic neighborhood" size. "N" was defined as the number of English words that could be produced by replacing one letter while preserving letter position for all other letters. The final stimulus list consisted of words and nonwords with either a high or a low value of $\mathrm{N}$.

Coltheart et al. (1977) used a lexical decision task (LDT); in this task, the subject is required to decide if a stimulus item, shown on a computer screen, is a word or a nonword. The authors found an effect of $\mathrm{N}$ only for nonword trials; that is, having many similar (word) neighbors considerably slowed the "nonword" response. There was no effect for words, which led Coltheart et al. to conclude that the number of items physically similar to a given word is not related to the response time (RT) to recognize it as a word.

However, new evidence suggests that other properties of a neighborhood do affect visual word recognition, and recent work has found that the effect of the size of a word's neighborhood on RT is not quite as clear as it initially appeared in Coltheart et al.'s (1977) study. ${ }^{1}$ A number of experiments (e.g., Stadtlander, 1990, 1995) have supported Coltheart et al.'s finding that there is no effect of neighborhood size. However, others (Andrews, 1989, Experiments 1 and 2; Forster \& Shen, 1996; Sears, Hino, \& Lupker, 1995) have reported a significant difference for word stimuli, with large neighborhoods showing a faster RT than small neighborhoods.

Results such as those of Andrews (1989), Forster and Shen (1996), and Sears et al. (1995) suggest that the process of recognizing a word and making a lexical decision may be affected by specific attributes of the target word and/or the word's neighbors. Researchers have examined a number of possible attributes in a neighborhood context, including frequency of the target word, frequency of neighbors of the target word, and number of letter positions contributing to the neighborhood.

Since the first use of the LDT, RT has been shown to be a sensitive measure of frequency (Forster \& Chambers, 
1973; Rubenstein, Garfield, \& Millikan, 1970; Taft, 1979; Whaley, 1978). Thus, common words (i.e., ones of highfrequency in a language), such as door, are responded to more quickly in the LDT than are uncommon words (i.e., ones of low frequency in a language), such as cask. Virtually all research on neighborhood effects in which the target word's frequency has varied within the experiment report a target-word frequency effect. High-frequency target words are responded to faster than low-frequency words.

The evidence is conflicting on whether the frequency of the target word's neighbors affects RT. Grainger (1990), using large neighborhoods with low- and mediumfrequency target words in a LDT, developed four classes of words: (1) words with zero neighbors, (2) words with neighbors of only lower frequencies, (3) words with one neighbor of higher frequency, and (4) words with more than one neighbor of higher frequency. Grainger found that when the target had one or more neighbors of higher frequency, RT was slowed. A similar finding for lowfrequency target words was reported by Stadtlander (1990). However, Forster and Shen (1996) found no consistent inhibitory effect of high-frequency neighbors, and, to complicate the issue further, Sears et al. (1995) found high-frequency neighbors to facilitate processing of the target words.

Johnson and Pugh (1994) have recently reported that the number of letter positions contributing to the neighborhood (or word cohort) also has an effect. The authors report that as the number of letter positions yielding neighbors increases, an increase in interference is evident. It is Johnson and Pugh's opinion that it is not the size of a word's neighborhood that is the critical factor, but rather the number of letter positions contributing to the neighborhood.

Why are such inconsistencies present across experiments? One obvious reason is that thus far there has been no recognized standard of measuring neighborhoods used in these different studies. Each experimenter has devised his or her own word neighborhoods, using a variety of databases and criteria for neighborhood size and frequency.

The development of stimulus lists in this area has tended to be a laborious and complex process. The typical procedure has involved selecting a large number of words on the basis of their frequency (e.g., Forster \& Shen, 1996), compiling their neighborhoods, and selecting the final list on the basis of their target frequency and neighborhood size (e.g., Andrews, 1992). Other characteristics of the neighborhood (such as letter position, number of highfrequency neighbors, total neighborhood frequency), if not of specific interest in the study, tend to be ignored because of the complexity involved in compiling a balanced stimulus list. The purpose of the present study was to develop a large set of word neighborhoods which would specify the size, frequency, and number of positions contributing to the neighborhoods.

An additional area of concern is that researchers have varied, for no obvious reason, in using either 4- or 5-letter stimuli. Those using 5-letter target words have tended to report an inhibitory effect of neighborhood frequency (e.g.,
Grainger, O'Regan, Jacobs, \& Segui, 1989; Stadtlander, 1990; though see Sears et al., 1995, for a contrary finding). In contrast, those using 4-letter stimuli have indicated no inhibitory effect (Sears et al., 1995). Therefore, words of both 4 and 5 letters are included in the present study.

\section{METHOD OF COMPILATION OF WORD NEIGHBORHOODS}

In the present study, Coltheart et al.'s (1977) "N" definition is utilized. Thus, an orthographic neighborhood is defined as the number of English words produced by replacing one letter while preserving letter positions for all other letters. This definition of a neighborhood should be considered a rough metric of orthographic similarity and not necessarily a realistic portrayal of lexical processing.

All of the target words came from the stimulus lists of Andrews (1989, 1992), Coltheart et al. (1977), Johnson and Pugh (1994), Sears et al. (1995), and Stadtlander (1990, 1995). All of the 800 words contained 4 or 5 letters. The word lists were devised relative to the key elements that have been identified in the above literature: (1) target-word frequency (based upon Kučera and Francis, 1967), (2) number of words in the neighborhood, (3) number of words higher in frequency than the target word (per Grainger, 1990, and Grainger et al., 1989), (4) number of letter positions contributing to the neighborhood (per Johnson \& Pugh, 1994), and (5) summation of the frequency of all neighbors (providing a standard metric for high- vs. lowfrequency neighborhoods). In the present compilation, an effort was made to be impartial in selecting words for neighborhoods by selecting all words found in the relevant databases. Thus, included in neighborhoods are personal names (e.g., Mark, Mary). Note that many of these names have high Kučera and Francis (1967) frequency counts (e.g., Mary has a frequency of 88 per million); the author leaves it to individual researchers to choose whether to include such items in the neighborhood counts.

The neighborhoods were constructed primarily through the use of the WordPerfect (Version 5.0) and Word for Windows (Version 2.0) spell checkers. Documentation for WordPerfect 5.0 reports that it contains 115,000 words in its lexicon. The technical support for Word for Windows reports that its lexicon contains 104,000 words from the Standard English Dictionary. Counts of 4- and 5-letter words contained in these packages are not available. In these word-processing packages, a "wild card" character can be used to replace a letter in a word. The spell-check program then lists all words from its word lexicon whose letters are positionally consistent within the word. The total number of consistent words across all positions constitutes the neighborhood for a particular word, as defined in this study. For example, the target word blank would generate a neighborhood consisting of clank, flank, plank, blink, black, and bland.

Additionally, for each neighborhood, a summary neighborhood metric was devised with the format [A-B-C-D], whereby $\mathrm{A}=$ number of neighbors present in the neighbor- 
Table 1

Summary of Neighborhood Metrics for 4-Letter Words

\begin{tabular}{cccccr}
\hline $\begin{array}{c}\text { Target } \\
\text { Frequency }\end{array}$ & $\begin{array}{c}\text { Mean No. } \\
\text { of Neighbors }\end{array}$ & $\begin{array}{c}\text { Mean No. of } \\
\text { Higher Frequency } \\
\text { Neighbors }\end{array}$ & $\begin{array}{c}\text { Mean No. of } \\
\text { Positions Used }\end{array}$ & $\begin{array}{c}\text { Mean } \\
\text { Neighborhood } \\
\text { Frequency }\end{array}$ & $n$ \\
\hline $1,000+$ & 6.16 & 0.16 & 2.16 & 1,877 & 6 \\
$500-999$ & 11.00 & 0.66 & 2.93 & 2,072 & 15 \\
$300-499$ & 6.61 & 0.33 & 2.22 & 1,112 & 18 \\
$200-299$ & 9.00 & 0.39 & 2.73 & 766 & 23 \\
$100-199$ & 9.24 & 1.08 & 2.64 & 720 & 50 \\
$50-99$ & 9.32 & 1.68 & 2.92 & 665 & 25 \\
$20-49$ & 8.56 & 1.94 & 2.67 & 420 & 48 \\
$10-19$ & 8.16 & 2.89 & 2.48 & 492 & 69 \\
$5-9$ & 7.32 & 3.12 & 2.36 & 434 & 50 \\
$1-4$ & 7.29 & 4.11 & 2.36 & 366 & 46 \\
0 & 3.60 & 2.05 & 1.18 & 183 & 21 \\
Overall Mean & 7.84 & 1.67 & 2.42 & 827 & $N=371$ \\
\hline
\end{tabular}

hood (excluding the target word), $\mathrm{B}=$ number of neighbors higher in frequency than the target word, $\mathrm{C}=$ number of letter positions contributing neighbors to the neighborhood, and $\mathrm{D}=$ summed frequency of the neighborhood (including the target word). As an example, the target word blank leads to the generation of 6 neighbors $(A=6)$. Blank, with a Kučera and Francis (1967) frequency of 14 per million, has one neighbor higher in frequency (black, with a frequency of 203), thus $B=1$. Four letter positions contributed to constructing the neighborhood, thus $C=4$. For the final portion of the metric, all of the frequencies are summed, $D=233$. The entry for this orthographic neighborhood in the present compilation would be:

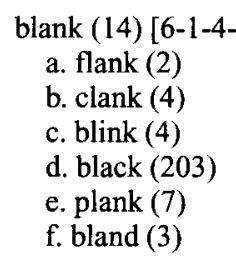

\section{RESULTS AND DISCUSSION}

Tables 1 and 2 summarize the neighborhood metrics for the 4- and 5-letter words. Appendix A lists the 4-letter target words in alphabetical order, with their frequency per million in parentheses and their summary metric in brackets. Appendix B lists the 5-letter words in alphabetical order. A copy of the detailed computerized listing of all word neighborhoods is available on disk from the author.

Differences are evident between 4- and 5-letter word stimuli, with 4-letter target words having a slightly higher mean frequency $(M=107.29)$ than 5-letter target words $(M=92.96)$. Additionally, as shown in Tables 1 and 2, 4letter words have a higher mean number of neighbors $(M=$ $7.84)$ than do 5-letter words $(M=4.57)$.

The neighborhood metrics generated in the present study suggest that the contrary findings reported in the literature may be due, at least in part, to differences in the frequency of the overall neighborhoods for 4- and 5-letter words. Shown in Table 3 are comparisons of overall neighborhood frequency and number of neighbors for 4- and 5letter stimuli. The table shows quite clearly that, for the samples in the present study (taken from studies in this area), the 4-letter words tend to have much higher total neighborhood frequency for the larger neighborhoods (i.e., larger neighborhood = more neighbors). Consequently, in a given experiment using 4-letter words, neighborhood size would tend to be confounded with neighborhood frequency: "large neighborhoods" would tend to have high neighborhood frequency, while "small neighborhoods" would tend to have low neighborhood frequency. On the

Table 2

Summary of Neighborhood Metrics for 5-Letter Words

\begin{tabular}{cccccc}
\hline $\begin{array}{c}\text { Target } \\
\text { Frequency }\end{array}$ & $\begin{array}{c}\text { Mean No. } \\
\text { of Neighbors }\end{array}$ & $\begin{array}{c}\text { Mean No. of } \\
\text { Higher Frequency } \\
\text { Neighbors }\end{array}$ & $\begin{array}{c}\text { Mean No. of } \\
\text { Positions Used }\end{array}$ & $\begin{array}{c}\text { Mean } \\
\text { Neighborhood } \\
\text { Frequency }\end{array}$ & $n$ \\
\hline $1,000+$ & 1.60 & 0.20 & 1.20 & 2,512 & 5 \\
$500-999$ & 3.50 & 0.25 & 1.63 & 1,322 & 8 \\
$300-499$ & 5.11 & 0.38 & 1.78 & 742 & 18 \\
$200-299$ & 3.56 & 0.08 & 1.91 & 346 & 23 \\
$100-199$ & 5.72 & 0.29 & 2.47 & 296 & 51 \\
$50-99$ & 5.13 & 0.82 & 2.15 & 254 & 39 \\
$20-49$ & 4.46 & 0.82 & 1.84 & 194 & 45 \\
$10-19$ & 4.95 & 2.58 & 2.06 & 159 & 62 \\
$5-9$ & 4.62 & 1.38 & 2.18 & 89 & 91 \\
$1-4$ & 4.96 & 2.79 & 2.24 & 181 & 77 \\
0 & 6.73 & 4.46 & 3.06 & 245 & 15 \\
Overall Mean & 4.57 & 1.27 & 2.05 & 576 & $N=434$ \\
\hline
\end{tabular}


Table 3

4- and 5-Letter Words by Number of Neighbors and Total Neighborhood Frequency

\begin{tabular}{ccc}
\hline Number of Neighbors & 4-Letter Words & 5-Letter Words \\
\hline $15-28$ & 1,577 & 358 \\
$10-14$ & 855 & 287 \\
$7-9$ & 328 & 214 \\
6 & 369 & 190 \\
5 & 654 & 222 \\
4 & 266 & 122 \\
3 & 486 & 264 \\
2 & 189 & 231 \\
1 & 198 & 269 \\
0 & 74 & 45 \\
\hline
\end{tabular}

other hand, an experiment with 5-letter words would tend to have similar total neighborhood frequency for both the large and small neighborhoods. Thus far, only three experimenters have controlled neighborhood size and frequency in the same experiment (Forster \& Shen, 1996; Sears et al., 1995; Stadtlander, 1990). However, no resolution can be drawn from these studies on the issue of 4versus 5-letter words and neighborhood size and frequency. Forster and Shen (1996) and Sears et al. (1995) used only low-frequency target words; Stadtlander (1990) used both low- and high-frequency target words, but only for 5-letter words. It remains to be seen whether this confound of neighborhood size and neighborhood frequency, which is present for 4-letter words but not for 5-letter words, contributes to the discrepant findings reported in the literature.

\section{REFERENCES}

ANDREWs, S. (1989). Frequency and neighborhood size effects on lexical access: Activation or search? Journal of Experimental Psychology: Learning, Memory, \& Cognition, 15, 802-814.

ANDREws, S. (1992). Frequency and neighborhood effects on lexical access: Lexical similarity or orthographic redundancy? Journal of Experimental Psychology: Learning, Memory, \& Cognition, 18, 234-254.

Coltheart, M., Davelaar, E., Jonasson, J. T., \& Besner, D. (1977). Access to the internal lexicon. In S. Dornic (Ed.), Attention and performance $V I$ (pp. 535-555). Hillsdale, NJ: Erlbaum.

Forster, K. I., \& Chambers, S. M. (1973). Lexical access and naming time. Journal of Verbal Learning \& Verbal Behavior, 12, 627-635.

FORSTER, K. I., \& SHEN, D. (1996). No enemies in the neighborhood: Absence of inhibitory neighborhood effects in lexical decision and semantic categorization. Journal of Experimental Psychology: Learning, Memory, \& Cognition, 22, 696-713.
GiBson, E. J. (1969). Principles of perceptual learning and development. New York: Appleton-Century-Crofts.

GraINGER, J. (1990). Word frequency and neighborhood frequency effects in lexical decision and naming. Journal of Memory \& Language, 29, 228-244.

Grainger, J., O'Regan, J. K., Jacobs, A. M., \& Segui, J. (1989). On the role of competing word units in visual word recognition. Perception \& Psychophysics, 47, 191-198.

GunTher, H., \& GreEse, B. (1985). Lexical hermits and the pronunciation of visually presented words. Forschungsberichte des Institut für Phonetik und sprachliche Kommunikation des Universität München, 21, 25-52

JoHNSON, N. F., \& PUGH, K. R. (1994). A cohort model of visual word recognition. Cognitive Psychology, 26, 240-346.

KuČERA, H., \& FrANCIS, W. N. (1967). Computational analysis of presentday American English. Providence, RI: Brown University Press.

Laxon, V. J., Coltheart, V., \& Keating, C. (1988). Children find friendly words friendly too: Words with many orthographic neighbors are easier to read and spell. British Journal of Educational Psychology, 58, 103-119.

LuCE, P. A. (1986). Neighborhoods of words in the mental lexicon. In Research on speech perception (Tech. Rep. No. 6). Bloomington: Indiana University, Department of Psychology.

Monsell, S., Doyle, M. C., \& HagGard, P. N. (1989). Effects of frequency on visual word recognition tasks: Where are they? Journal of Experimental Psychology: General, 118, 43-71.

Rubenstein, H., Garfield, L., \& Millikan, J. A. (1970). Homographic entries in the internal lexicon. Journal of Verbal Learning \& Verbal Behavior, 9, 487-492.

SCHEERER, E. (1987). Visual word recognition in German. In D. A. Allport, D. Mackay, W. Prinz, \& E. Scheerer (Eds.), Language perception and production: Shared mechanism in listening, speaking, reading, and writing (pp. 227-244). London: Academic Press.

Sears, C. R., Hino, Y., \& LuPKER, S. J. (1995). Neighborhood size and neighborhood effects in word recognition. Journal of Experimental Psychology: Human Perception \& Performance, 21, 876-900.

STADTLANDER, L. M. (1990). A frequency-verification model of visual word recognition: Frequency effects within a neighborhood of words. Unpublished master's thesis, Ohio State University.

STADTLANDER, L. M. (1995). Age differences in orthographic and frequency neighborhoods. In P. Allen \& T. R. Bashore (Eds.), Age differences in word and language processing (pp. 72-86). Amsterdam: Elsevier.

TAFT, M. (1979). Lexical access via an orthographic code: The basic orthographic syllabic structure (BOSS). Journal of Verbal Learning \& Verbal Behavior, 18, 21-39.

WhALEY, C. P. (1978). Word-nonword classification time. Journal of Verbal Learning \& Verbal Behavior, 17, 143-154.

\section{NOTE}

1. Neighborhood effects have also been reported in studies of accuracy of identification of masked words (Luce, 1986), children's naming (Laxon, Coltheart, \& Keating, 1988), and naming latency for German words (Gunther \& Greese, 1985; Scheerer, 1987). 


\section{APPENDIX A}

4-Letter Target Words

\begin{tabular}{|c|c|c|}
\hline \multicolumn{3}{|c|}{$\begin{array}{l}\text { Kučera and Francis (1967) frequency per million in parentheses. Neighborhood metric [A-B-C-D], whereb } \\
\mathrm{A}=\text { number of neighbors present in the neighborhood (excluding the target word), } \mathrm{B}=\text { number of neighbor } \\
\text { higher in frequency than the target word, } \mathrm{C}=\text { number of letter positions contributing neighbors to the neigh } \\
\text { borhood, and } \mathrm{D}=\text { summed frequency of the neighborhood (including the target word). }\end{array}$} \\
\hline able (216) [2-0-2-223] & $\operatorname{coin}(10)[8-3-4-145]$ & fuel (17) $[4-2-3-468]$ \\
\hline acid (13) [4-1-2-30] & cold (171) [12-1-3-951] & full (230) $[14-0-3-642]$ \\
\hline acre (9) $[3-0-1-13]$ & colt (18) [13-3-4-487] & fury (19) [4-1-2-97] \\
\hline adds $(10)[3-2-2-51]$ & come (630) [17-1-4-3621] & fuse (19) [4-0-2-29] \\
\hline also (1069) [2-0-1-1073] & core (37) $[26-5-4-3353]$ & gaff $(0)[0-0-0-0]$ \\
\hline anew (6) $[1-1-1-401]$ & corn (34) $[14-2-3-301]$ & gala (7) $[3-0-2-9]$ \\
\hline area $(323)[2-0-2-324]$ & cove (2) [15-11-2-1168] & game (123) [14-4-2-2098] \\
\hline army (132) [2-0-1-254] & cult (11) $[4-2-3-61]$ & gang (22) $[9-2-2-109]$ \\
\hline aunt (22) $[4-0-1-36]$ & curb (13) $[4-1-1-49]$ & gash (1) [12-7-3-104] \\
\hline away (456) [2-0-2-463] & cusp (2) $[1-0-1-2]$ & gasp (3) $[5-0-2-8]$ \\
\hline bank (83) $[17-1-4-1223]$ & cute $(9)[7-2-4-73]$ & gene (9) $[2-1-2-204]$ \\
\hline bard (3) $[16-12-3-516]$ & dame (7) $[19-11-4-1994]$ & germ $(0)[2-1-1-79]$ \\
\hline bark (14) $[12-6-3-1466]$ & dare (21) $[19-6-4-617]$ & gill (2) [17-13-4-2908] \\
\hline barn (29) $[11-2-3-284]$ & dark (185) $[10-0-3-406]$ & girl (220) $[2-0-2-223]$ \\
\hline bash (0) [15-14-3-241] & data (173) [3-0-2-279] & glib (1) $[1-0-1-1]$ \\
\hline bass (16) [15-5-4-389] & days $(384)[15-0-2-770]$ & glow (16) $[7-4-2-251]$ \\
\hline bats (6) $[20-9-3-182]$ & deaf (12) $[5-4-2-434]$ & golf (34) $[4-1-4-114]$ \\
\hline bear $(57)[21-5-4-1517]$ & deal (142) [17-2-4-755] & gown $(16)[6-2-1-1126]$ \\
\hline beta (2) $[4-2-2-10]$ & dear $(64)[17-6-3-1776]$ & grew (64) $[5-0-3-261]$ \\
\hline bill (143) [18-1-3-2811] & debt (13) $[2-0-1-17]$ & grey (12) $[5-2-3-137]$ \\
\hline bite (10) [12-2-3-110] & deed $(8)[14-6-3-829]$ & grim (14) $[8-2-2-83]$ \\
\hline blue (143) [5-0-2-169] & $\operatorname{deep}(109)[9-1-2-433]$ & gulp (2) $[3-2-2-30]$ \\
\hline boat (72) $[10-0-4-220]$ & deny (47) $[4-0-2-57]$ & gyms (0) [3-2-1-6] \\
\hline body $(276)[4-0-2-286]$ & desk (65) [3-0-2-122] & gyro (26) $[0-0-0-26]$ \\
\hline bold (21) [13-6-4-1044] & dine (2) $[22-12-4-1060]$ & hair (148) $[4-0-2-285]$ \\
\hline bomb (36) $[4-0-2-48]$ & $\operatorname{disc}(6)[2-2-1-47]$ & half $(275)[5-0-2-452]$ \\
\hline boot (13) [18-4-4-387] & doff $(0)[0-0-0-0]$ & halt $(10)[10-3-4-244]$ \\
\hline born (113) [10-0-4-297] & dome (17) $[15-5-2-3230]$ & hand (431) $[8-0-3-981]$ \\
\hline both (730) [3-0-2-762] & done $(320)[20-0-4-808]$ & hang (26) [12-3-3-634] \\
\hline brag (2) $[8-1-3-21]$ & down $(895)[6-0-3-1152]$ & hawk (14) $[5-1-3-37]$ \\
\hline buck $(20)[10-2-3-1089]$ & dual (9) $[4-2-2-184]$ & heap (14) $[8-4-3-1018]$ \\
\hline buff (5) $[6-1-1-18]$ & dumb (13) $[2-0-2-21]$ & high (497) [3-0-2-518] \\
\hline bulb (7) $[2-2-1-37]$ & easy (125) $[2-1-1-350]$ & hill (72) [16-3-3-2929] \\
\hline bulk (16) [7-2-4-77] & echo (10) $[0-0-0-10]$ & hint (9) $[8-2-4-53]$ \\
\hline bump (5) [9-4-3-57] & envy (7) $[0-0-0-7]$ & hire (15) [11-5-3-1051] \\
\hline bunk (18) $[16-2-3-170]$ & epic $(18)[1-0-1-21]$ & hobo (1) $[3-0-3-3]$ \\
\hline buoy $(0)[2-2-1-64]$ & ever $(345)$ [4-2-3-2752] & hold (169) [12-2-4-1134] \\
\hline busy (58) $[5-0-2-86]$ & fact $(447)[5-0-2-907]$ & holy (49) $[2-2-1-276]$ \\
\hline buzz (13) $[1-0-1-16]$ & fair (77) $[5-2-2-362]$ & home (547) [10-2-2-3128] \\
\hline cage (9) [13-10-2-1373] & farm $(125)[5-0-3-335]$ & hook (5) $[13-6-3-1089]$ \\
\hline calf (11) [3-3-2-509] & fear (127) [11-3-2-1359] & hoot (9) $[13-4-3-183]$ \\
\hline call $(188)$ [13-0-3-967] & fend $(0)[14-11-4-758]$ & horn (31) [6-2-1-226] \\
\hline came (622) [19-2-4-2963] & feud (1) $[2-1-1-128]$ & hour (144) $[5-2-1-1464]$ \\
\hline cape (20) $[18-5-4-1296]$ & film (96) $[3-1-2-336]$ & huge $(54)[2-0-1-63]$ \\
\hline care (162) [24-2-4-1647] & firm (109) $[6-2-4-530]$ & hull (13) $[15-7-4-675]$ \\
\hline cart (5) $[14-10-3-957]$ & fish (35) $[3-1-2-187]$ & hymn (9) $[0-0-0-9]$ \\
\hline case (362) [13-1-3-1397] & fizz $(0)[1-1-1-3]$ & idea (195) [1-0-1-195] \\
\hline cave (9) $[17-12-3-5598]$ & flag (16) [7-1-3-87] & idol (7) $[0-0-0-7]$ \\
\hline cell (65) $[13-5-3-1658]$ & flax (3) $[8-3-1-121]$ & itch (5) $[2-1-2-45]$ \\
\hline cent (158) [11-1-3-903] & flea (2) $[5-3-2-71]$ & jinx (1) $[2-0-2-1]$ \\
\hline chef $(9)[2-0-2-11]$ & flew (27) $[9-2-3-142]$ & jury (67) [4-0-2-165] \\
\hline chug $(0)[2-2-2-2]$ & flux $(30)[4-0-2-32]$ & kept (186) [1-0-1-195] \\
\hline chum (1) $[1-0-1-1]$ & foal (2) $[7-6-3-193]$ & kick (16) $[10-4-2-176]$ \\
\hline city $(0)[2-2-2-15]$ & foil (20) $[11-3-3-174]$ & knee (35) $[1-1-1-430]$ \\
\hline clay $(100)[9-0-4-112]$ & folk (34) $[3-0-3-56]$ & knew (395) [3-1-3-1119] \\
\hline club (145) [2-0-2-160] & food (147) $[10-1-3-984]$ & knit (10) $[3-1-2-121]$ \\
\hline clue (15) $[5-2-2-311]$ & form (370) [11-0-4-755] & know (683) [4-0-3-1147] \\
\hline $\operatorname{coax}(1)[3-2-2-76]$ & free $(260)[4-0-3-348]$ & lamb (7) $[5-0-3-32]$ \\
\hline
\end{tabular}


APPENDIX A (Continued)

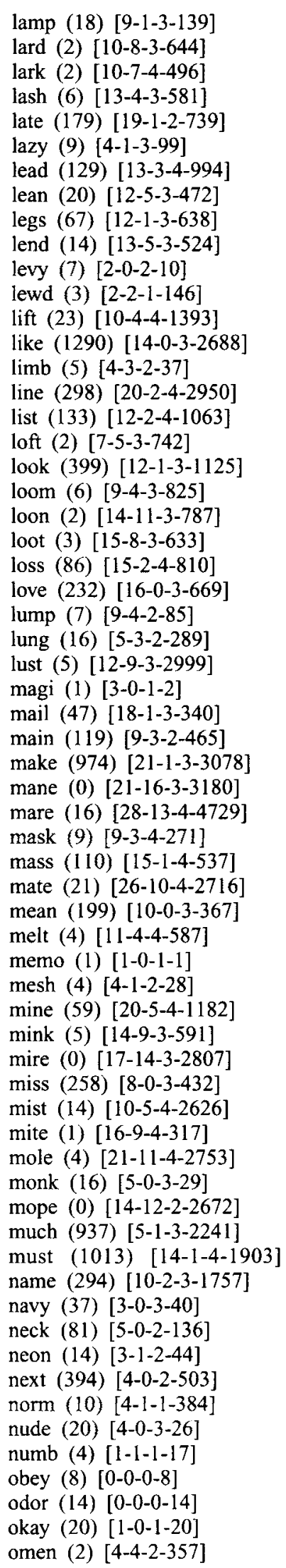

once (499) [0-0-0-499]

only (1747) [1-0-1-1757]

open (319) [3-0-1-338]

over (1236) [3-0-2-1588]

pant (0) [10-7-4-806]

park (94) [11-2-4-919]

part (500) [16-0-4-946]

past (281) [12-2-4-2007]

path (44) [8-0-3-85]

peak (16) [11-2-3-87]

peer (8) [12-2-3-70]

pelt (0) $[10-5-2-396]$

pica (0) [3-2-3-56]

pill (15) [16-8-3-2757]

pink (48) [13-1-3-195]

pint (13) [13-2-4-104]

pity (14) [4-1-3-410]

pixy (0) [1-1-1-14]

plan (205) [5-0-2-412]

plot (37) [8-0-3-65]

poem (48) [1-1-1-147]

pole (18) [18-5-4-356]

pond (25) [4-1-2-148]

pool (111) [7-1-3-380]

poor (113) [7-1-3-554]

pose (11) [13-6-3-391]

pulp (5) [4-2-3-69]

pump (11) [11-1-3-64]

quit (15) [4-0-2-25]

race (103) [13-1-3-299]

raft (4) [6-0-3-10]

rage (16) [13-6-3-743]

rake (11) [16-20-2-1913]

rare (41) [16-3-2-624]

rash (1) [13-7-3-119]

$\operatorname{rasp}(2)$ [6-2-3-14]

rate (209) [21-0-3-1057]

real (260) [15-0-3-694]

rely (13) [0-0-0-13]

rest (163) [12-2-2-950]

rich (0) [2-1-1-33]

ride (49) [18-3-4-804]

rind $(0)$ [8-8-2-1159]

rink (2) [12-9-4-283]

ripe (14) [13-5-4-275]

rise (102) [13-0-4-435]

road (194) [8-0-3-436]

role (104) [16-0-3-425]

rope (15) [16-6-3-517]

rosy (9) [2-1-2-95]

ruin (14) [2-1-1-87]

rush $(20)$ [10-2-4-117]

same (686) [16-1-3-3574]

sari (1) [1-1-1-5]

says (200) [17-1-2-772]

scar (10) [9-1-2-42]

seam (9) [14-6-3-440]

seat (54) [13-2-4-412]

seem (229) [10-0-4-615]

sexy (2) [0-0-0-2]

shot (112) [11-1-3-589]

show (287) [9-0-3-540]

side (380) [11-0-2-804] sigh (11) [3-1-2-106]

sign (94) [1-0-1-105]

sink (23) [14-2-4-251]

sire (0) [17-13-4-1131]

size (138) [4-1-1-586]

skin (47) [8-0-2-74]

slab (9) [11-0-3-24]

slim (20) [9-1-4-96]

slow (60) [14-2-3-546]

slum (8) [10-2-4-45]

snag (3) [6-2-3-26]

snob (9) [5-1-4-80]

soak (7) [3-1-2-33]

soft (61) [6-1-4-234]

soon (199) [8-0-3-293]

sort (164) [7-0-3-312]

soup (16) [4-2-2-92]

span (19) [11-0-3-62]

spat (9) [11-4-3-152]

spit (11) [7-2-3-137]

stem (29) [4-3-3-448]

stir (7) [1-1-1-32]

stop (120) [5-1-4-322]

stow (0) [6-5-3-531]

such (1303) [3-0-2-2248]

suck (8) [14-5-3-1458]

sung (18) [11-3-3-214]

sunk (9) [15-4-4-115]

sure (264) [6-0-3-366]

swam (1) [12-5-3-31]

take (611) [13-1-3-1601]

talk (154) [8-0-3-406]

tang (4) [11-7-3-134]

taut (8) [4-0-2-23]

tent (20) [16-8-4-1127]

term (79) [5-1-3-165]

test (119) [12-3-2-998]

thud (3) [2-1-1-316]

thus (312) [3-1-2-5462]

tide (11) [13-7-3-2236]

tile (16) [16-7-4-1889]

tomb (11) [4-1-2-54]

town (212) [7-1-2-1151]

trap (20) [5-1-3-127]

tree (59) [4-2-4-567]

trim (20) [7-1-3-139]

trio (9) $[3-3-1-120]$

trot (12) [4-0-2-18]

true (231) [1-0-1-290]

tube (31) [5-0-3-48]

turn (233) [5-0-3-281]

type (200) [4-0-3-235]

unit (103) [2-0-1-113]

upon (495) [0-0-0-495]

urge (21) $[0-0-0-21]$

used (612) [2-0-1-675]

vein (25) $[3-0-3-46]$

verb (4) [2-1-2-807]

very (796) $[1-0-1-830]$

veto (10) $[1-0-1-10]$

view (186) [2-0-1-188]

void (10) [0-0-0-10]

vote (75) [6-1-2-203] 
APPENDIX A (Continued)

\begin{tabular}{lll}
\hline walk (100) $[5-2-2-415]$ & well (897) $[15-1-4-3899]$ & word (274) $[10-1-3-1320]$ \\
wall (160) [14-4-3-4169] & went (507)[17-0-4-1477] & yelp (2) [3-2-2-324] \\
wand (1) $[10-7-3-1169]$ & whip (19)[7-1-2-133] & yoke (3) [5-3-2-46] \\
ward (15) $[14-6-4-655]$ & wide $(125)[14-2-3-988]$ & zero (24) $[1-1-1-76]$ \\
weep (14) $[8-4-2-687]$ & wolf (6) $[2-1-2-40]$ & \\
\hline
\end{tabular}

\section{APPENDIX B \\ 5-Letter Target Words}

Kučera and Francis (1967) frequency per million in parentheses. Neighborhood metric [A-B-C-D], whereby $\mathrm{A}=$ number of neighbors present in the neighborhood (excluding the target word), $\mathrm{B}=$ number of neighbors higher in frequency than the target word, $\mathrm{C}=$ number of letter positions contributing neighbors to the neighborhood, and $\mathrm{D}$ = summed frequency of the neighborhood (including the target word).

\begin{tabular}{|c|c|c|}
\hline about (1815) [1-0-1-1815] & burst (33) [1-0-1-39] & creak (1) [6-5-4-136] \\
\hline above (296) [1-0-1-300] & cabin $(23)[0-0-0-23]$ & creep (10) [2-1-1-32] \\
\hline adapt (5) $[2-1-1-22]$ & cases $(148)[15-0-4-223]$ & crime (34) [6-1-4-81] \\
\hline after $(1070)$ [3-0-1-1085] & cater (4) $[8-3-3-852]$ & crisp (8) $[1-0-1-8]$ \\
\hline again $(578)[0-0-0-578]$ & cause $(130)[1-0-1-151]$ & crock $(0)[7-5-4-4-47]$ \\
\hline alien (16) $[1-0-1-18]$ & cedar (1) $[0-0-0-1]$ & $\operatorname{cross}(55)[6-1-3-147]$ \\
\hline alone (195) $[2-1-2-550]$ & chain (50) $[1-1-1-116]$ & crown (19) $[8-3-4-300]$ \\
\hline angel (18) $[1-1-1-66]$ & chick (3) $[5-4-2-312]$ & crude (15) $[2-0-2-15]$ \\
\hline ankle (8) $[1-1-1-59]$ & chief (119) [1-0-1-127] & cured (7) $[6-1-4-29]$ \\
\hline apart (57) [1-0-1-57] & child $(213)[2-0-1-228]$ & cycle $(24)[0-0-0-24]$ \\
\hline apron (7) $[2-0-1-15]$ & chili (6) $[2-2-1-233]$ & dense (9) [2-2-1-335] \\
\hline areas $(236)[1-0-1-236]$ & chill (14) [3-1-1-234] & depth (53) [1-1-1-330] \\
\hline aside $(65)[1-0-1-72]$ & chins (2) $[5-3-4-83]$ & devil (25) $[0-0-0-25]$ \\
\hline awake $(20)[2-1-2-113]$ & choir (8) [1-1-1-74] & digit (1) $[0-0-0-1]$ \\
\hline bacon $(10)[2-0-1-22]$ & choke (9) $[2-1-1-53]$ & dives (4) [9-4-4-228] \\
\hline badge (5) $[2-1-2-15]$ & chord (7) $[1-0-1-14]$ & donor (5) $[2-1-2-71]$ \\
\hline baked (8) [11-2-3-179] & circa (1) $[0-0-0-1]$ & doubt (114) [0-0-0-114] \\
\hline baker (36) [10-0-4-59] & cites (10) [7-2-2-63] & dozed (5) $[10-1-4-69]$ \\
\hline bales (4) $[21-6-5-235]$ & civil $(91)$ [1-0-1-114] & drama $(43)[1-0-1-43]$ \\
\hline based (119) [9-0-4-162] & clamp (0) [6-4-4-9] & drawn (70) [6-0-4-97] \\
\hline basic (171) [3-1-1-363] & clank (0) [10-6-4-60] & dress (67) [5-1-3-203] \\
\hline batch (5) [8-4-2-193] & class $(207)$ [10-0-4-321] & drown (3) [5-4-2-312] \\
\hline beans (9) $[12-3-3-361]$ & clear $(219)[2-0-1-290]$ & dunes (8) [7-0-4-19] \\
\hline bears $(0)$ [18-13-4-1103] & cleat (1) [5-4-3-295] & dwell (8) [2-0-2-16] \\
\hline beats (4) $[17-7-3-149]$ & clerk (34) [1-1-1-69] & eager $(27)[4-0-1-30]$ \\
\hline begin (84) [2-1-1-447] & cliff (i 1) $[0-0-0-11]$ & early $(366)[1-0-1-366]$ \\
\hline being $(712)[1-0-1-870]$ & climb (12) $[1-0-1-12]$ & eight (104) $[7-5-1-2345]$ \\
\hline bills (47) [18-1-4-172] & clink $(0)[9-4-5-14]$ & elect (8) $[2-1-1-22]$ \\
\hline bison (1) $[0-0-0-1]$ & clock $(20)[8-1-3-104]$ & enter $(78)[3-0-2-80]$ \\
\hline bland (3) $[7-5-4-143]$ & clove (1) $[3-2-2-244]$ & every $(491)$ [2-0-2-492] \\
\hline blank (14) [6-1-4-233] & clown (3) $[3-3-2-35]$ & exact $(27)[2-0-2-35]$ \\
\hline bleak (10) [2-1-2-99] & coast (61) [3-0-1-98] & faces $(72)[13-1-3-251]$ \\
\hline bless (9) [1-0-1-13] & coats $(10)[8-2-3-255]$ & false (29) $[0-0-0-29]$ \\
\hline blimp (1) $[0-0-0-1]$ & coins $(9)[7-0-4-22]$ & feast (3) $[3-2-1-356]$ \\
\hline bloom (12) [3-2-2-149] & colon (2) $[1-1-1-143]$ & feeds (12) $[9-3-3-266]$ \\
\hline blows (8) $[9-1-4-32]$ & color (141) [2-0-2-143] & fetch (6) $[1-0-1-7]$ \\
\hline blunt (9) [2-0-2-10] & comes $(137)$ [12-0-4-312] & flair (8) $[2-0-2-11]$ \\
\hline bolts (1) [6-4-3-88] & comet (2) $[3-1-2-141]$ & flank (2) [10-4-3-96] \\
\hline boost (15) [2-0-2-24] & copes (1) [11-7-4-218] & fleet (17) $[2-0-2-19]$ \\
\hline bored (14) [11-0-3-27] & corps (109) [7-0-3-120] & flesh $(52)[3-1-2-166]$ \\
\hline brick (18) $[5-0-2-45]$ & costs $(176)[7-0-3-201]$ & flood (19) [2-2-2-298] \\
\hline brink (3) $[7-5-4-272]$ & couch $(12)[6-2-3-132]$ & floor $(158)[1-0-1-177]$ \\
\hline broil (2) $[0-0-0-2]$ & could (1599) [1-1-1-4313] & flour (8) $[2-1-2-166]$ \\
\hline brown (176) [7-0-4-257] & count (49) $[3-1-2-498]$ & fluid $(21)[0-0-0-21]$ \\
\hline brute $(6)[1-0-1-10]$ & court $(230)[1-0-1-279]$ & force $(230)$ [2-0-2-243] \\
\hline budge (3) [3-1-1-82] & cover $(88)[12-0-3-121]$ & forms $(128)[8-0-4-260]$ \\
\hline bugle (2) $[0-0-0-2]$ & cower $(0)[7-4-3-564]$ & forth (71) $[5-2-2-417]$ \\
\hline built (103) [3-0-2-222] & $\operatorname{crack}(21)[6-1-3-61]$ & forts (4) $[9-5-3-260]$ \\
\hline bully (4) [10-5-5-161] & crank (1) [5-4-4-114] & forum $(10)[0-0-0-10]$ \\
\hline
\end{tabular}


APPENDIX B (Continued)

\begin{tabular}{|c|c|c|}
\hline found $(411)$ [8-0-2-812] & lions (6) $[2-0-2-7]$ & plate (22) [8-2-3-737] \\
\hline fours (2) $[6-3-2-215]$ & lived $(115)$ [7-0-5-290] & plead (5) $[2-0-1-8]$ \\
\hline freak (4) $[2-1-1-93]$ & liver (16) [11-5-4-629] & plots (7) $[6-0-2-15]$ \\
\hline freed (12) [8-1-4-62] & lords (3) $[5-2-3-292]$ & poker (6) [6-1-4-355] \\
\hline frees (2) $[6-3-4-121]$ & louse (3) $[6-4-3-671]$ & polls (10) [9-4-4-80] \\
\hline front (221) [1-0-1-227] & lover (19) [13-3-4-346] & power $(342)$ [9-0-2-486] \\
\hline frost (6) $[1-1-1-227]$ & loves (19) [13-3-3-233] & price $(108)[5-0-3-225]$ \\
\hline froze $(5)[0-0-0-5]$ & lower (123) [11-1-2-500] & prime (45) [7-1-3-257] \\
\hline fuzzy (7) $[1-0-1-7]$ & loyal (18) $[3-2-3-354]$ & proof $(40)[0-0-0-40]$ \\
\hline gaily (5) $[1-1-1-127]$ & lunch (33) $[6-0-3-66]$ & props (6) $[8-2-4-42]$ \\
\hline ghoul (1) $[0-0-0-1]$ & lyric (12) $[0-0-0-12]$ & pulse (9) [1-1-1-23] \\
\hline girls $(142)$ [2-0-2-142] & major (247) [2-0-1-290] & pumps (5) $[11-10-4-14]$ \\
\hline gives (112) [8-1-3-617] & makes $(172)[14-0-3-316]$ & pupil $(20)[0-0-0-20]$ \\
\hline glass (99) [9-1-3-357] & manor (5) $[3-3-2-348]$ & quack (9) [2-1-2-79] \\
\hline gloom (14) [2-0-2-31] & maple (7) $[0-0-0-7]$ & quail $(0)[0-0-0-0]$ \\
\hline going (399) $[1-0-1-562]$ & marsh (4) $[2-2-2-136]$ & quake $(2)[1-0-1-2]$ \\
\hline grabs (3) $[5-2-3-77]$ & mates $(10)[15-5-3-377]$ & quest (2) $[1-1-1-41]$ \\
\hline grace $(40)[7-0-2-130]$ & mayor (38) [2-1-1-290] & quill (9) [2-0-2-12] \\
\hline grade $(35)[8-2-3-260]$ & means $(310)[9-0-3-454]$ & radii (4) $[2-1-1-124]$ \\
\hline grape (3) $[10-5-4-141]$ & meant $(100)[2-1-2-413]$ & raged $(8)[10-2-2-51]$ \\
\hline graph (17) $[1-0-1-20]$ & mercy $(20)[1-0-1-28]$ & raids (5) [1-1-1-17] \\
\hline grass (53) [9-2-5-279] & merit (29) [0-0-0-29] & rails (9) [12-2-2-73] \\
\hline grave (33) $[10-2-4-155]$ & meter (6) $[7-1-3-48]$ & rains (5) [10-5-4-76] \\
\hline great $(665)[2-0-2-698]$ & miles (173) [15-0-4-248] & rally (10) [2-1-1-27] \\
\hline greed (3) $[6-6-2-224]$ & mince (1) $[2-1-1-619]$ & $\operatorname{ranch}(27)[0-0-0-27]$ \\
\hline grief (10) $[1-1-1-83]$ & miner (1) $[9-6-4-98]$ & rates $(102)$ [16-0-4-215] \\
\hline grove (14) [6-3-4-172] & mines (28) [22-3-4-486] & reach $(106)[7-0-3-229]$ \\
\hline hands $(289)$ [9-0-4-361] & mirth (2) $[3-1-1-69]$ & react $(15)[1-1-1-121]$ \\
\hline handy (13) [8-4-4-397] & miser (0) $[7-2-3-12]$ & realm (19) $[1-0-1-19]$ \\
\hline hangs (4) $[5-3-2-307]$ & moist (11) [3-0-1-12] & repay (7) $[2-2-2-62]$ \\
\hline harsh (12) [1-0-1-16] & money $(265)$ [2-0-1-293] & repel (8) [2-1-1-29] \\
\hline hatch (5) [8-4-2-198] & month (130) [1-0-1-433] & right (613) [7-1-1-2345] \\
\hline heads (43) [10-0-4-112] & moods (8) [8-3-4-160] & rings (6) $[9-3-3-50]$ \\
\hline heart (173) [2-1-1-427] & motor $(56)[1-0-1-62]$ & risks (5) $[6-1-5-35]$ \\
\hline heave (2) $[3-3-2-321]$ & mouth (103) [2-1-2-315] & rites (4) $[7-6-3-170]$ \\
\hline heavy $(110)$ [1-0-1-112] & moved (181) [7-0-3-276] & river $(165)$ [8-0-4-203] \\
\hline hello (10) $[1-0-1-10]$ & muddy (10) $[2-1-1-26]$ & roach $(2)[3-2-2-133]$ \\
\hline hides (5) [10-1-4-129] & munch (1) $[5-5-2-69]$ & roman $(58)[1-1-1-282]$ \\
\hline hints (10) $[8-0-4-13]$ & needs $(152)[6-0-3-225]$ & roofs $(5)[5-3-2-94]$ \\
\hline hitch (5) [6-3-2-53] & nerve (12) $[2-1-1-123]$ & rouge (7) $[2-1-2-49]$ \\
\hline horns (8) $[2-0-1-10]$ & night (411) [7-2-1-2345] & round $(81)$ [7-2-1-937] \\
\hline hotel (126) [2-0-2-142] & noose (3) $[5-3-2-97]$ & ruins $(8)[2-1-1-22]$ \\
\hline hyena (1) $[0-0-0-1]$ & odder $(0)[3-2-2-467]$ & rumor $(8)[2-2-1-72]$ \\
\hline ideal (61) [1-1-1-204] & often $(368)$ [1-0-1-368] & safer (5) $[5-0-2-8]$ \\
\hline irons (7) $[2-1-2-19]$ & older (93) [3-1-2-485] & salem (19) [1-1-1-152] \\
\hline jolly (4) $[5-1-2-26]$ & olive $(5)[2-1-1-63]$ & sales (133) [16-0-5-225] \\
\hline khaki (1) $[0-0-0-1]$ & order (376) [2-0-1-469] & sauce $(20)[1-0-1-21]$ \\
\hline known $(245)[1-0-1-344]$ & paced (11) [10-2-3-92] & saves $(5)$ [12-4-3-240] \\
\hline label (19) $[3-0-3-25]$ & paint (37) $[6-1-3-767]$ & scale $(60)[6-0-2-72]$ \\
\hline labor (149) [1-0-1-149] & panel (31) $[2-0-1-35]$ & scare (3) $[11-7-4-282]$ \\
\hline laced (2) $[5-3-3-80]$ & paper (157) [8-0-2-167] & scene (106) [2-0-2-112] \\
\hline lance (3) [1-1-1-93] & parts (113) [13-1-5-440] & score $(66)[10-1-5-251]$ \\
\hline large $(361)$ [2-0-1-368] & peach (3) $[7-4-4-44]$ & scout (8) $[7-2-3-39]$ \\
\hline later (397) [12-1-4-859] & peers (8) [9-0-3-21] & scrap (8) $[2-0-1-10]$ \\
\hline latin $(50)[1-0-1-55]$ & piano $(38)[0-0-0-38]$ & scrub (9) $[1-0-1-10]$ \\
\hline learn (84) $[1-0-1-85]$ & piece (129) [1-0-1-137] & seeks (10) $[8-3-2-453]$ \\
\hline leash (3) $[2-2-1-356]$ & pilot (44) $[2-0-1-46]$ & seems (259) [9-0-4-355] \\
\hline least $(343)[7-0-3-371]$ & pipes (7) $[6-0-4-14]$ & sense $(311)[2-0-1-335]$ \\
\hline leave (205) [3-0-2-221] & pitch (22) $[5-0-3-52]$ & serve $(107)[2-0-2-124]$ \\
\hline light (333) [7-3-1-2345] & pizza (3) $[0-0-0-3]$ & seven (113) [2-0-2-116] \\
\hline liner (4) $[10-3-3-51]$ & plane $(114)[5-2-3-952]$ & shaft (11) $[2-1-2-52]$ \\
\hline lines (198) [16-0-5-300] & plank (7) $[9-4-4-375]$ & shale $(0)$ [1 $1-9-4-586]$ \\
\hline
\end{tabular}


APPENDIX B (Continued)

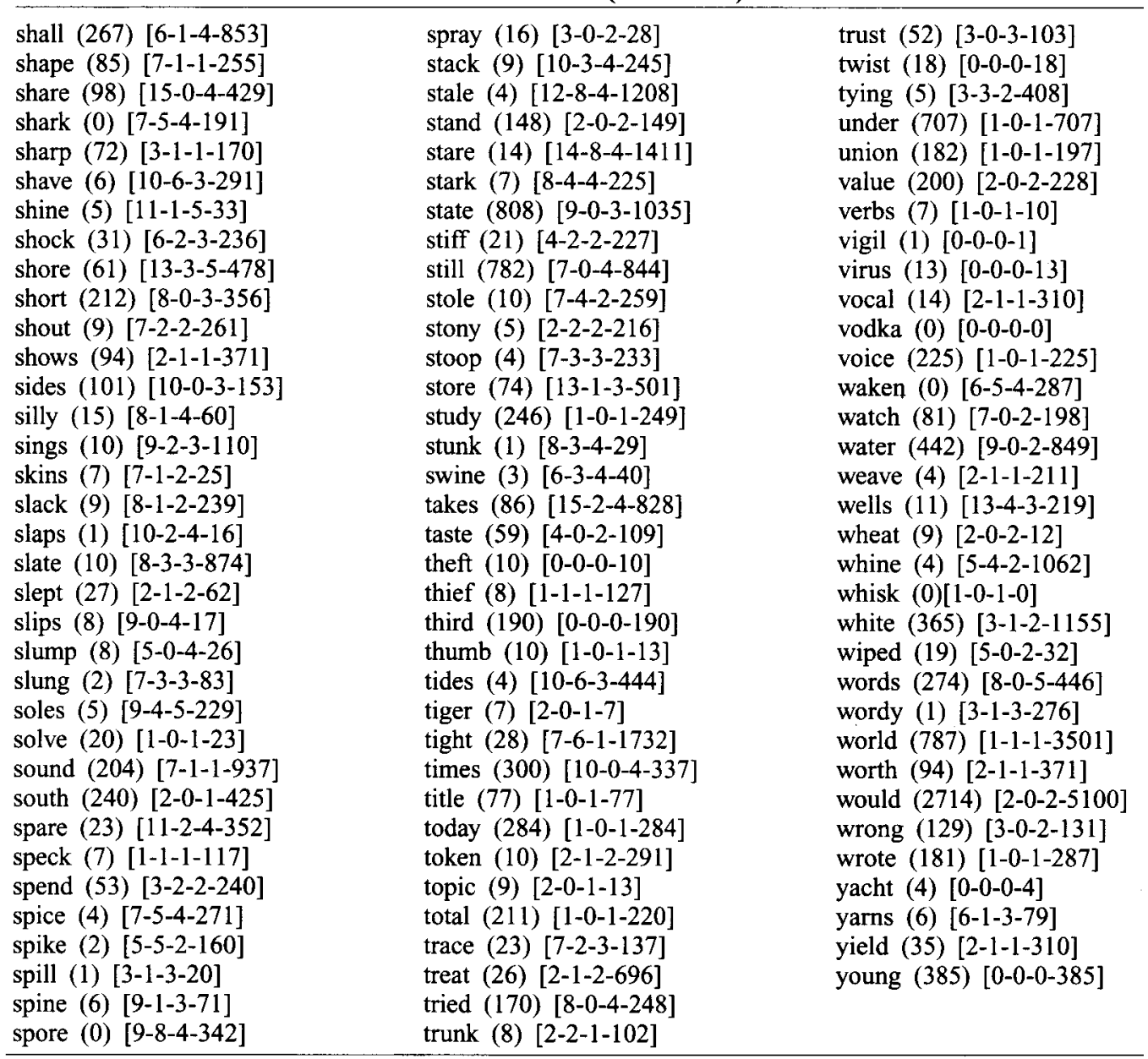

(Manuscript received March 25, 1996; revision accepted for publication November 26, 1996.) 